\title{
FAULTING DEFORMATION OF THE MESOHELLENIC TROUGH IN THE KASTORIA-NESTORION REGION (WESTERN MACEDONIA, GREECE)
}

\author{
Tranos M. D. ${ }^{1}$, Mountrakis D. M. ${ }^{1}$, Papazachos, C. B. ${ }^{2}$, Karagianni, E. ${ }^{2}$, \\ and Vamvakaris, D. $^{2}$ \\ ${ }^{1}$ Aristotle University of Thessaloniki, Department of Geology, 54124 Thessaloniki, Greece, \\ tranos@geo.gr,dmountra@geo.auth.gr \\ ${ }^{2}$ Aristotle University of Thessaloniki, Department of Geophysics, 54124 Thessaloniki, Greece, \\ cpapazachos@geo.auth.gr,elkarag@geo.auth.gr,dom@geo.auth.gr
}

\begin{abstract}
The Kastoria-Nestorion region, which belongs to the Tertiary MesoHellenic Trough (MHT), is a low relief NW-SE trending intermountainous basin filled with Tertiary molasse-type sedimentary rocks and nowadays drained by the Aliakmnonas River and its tributaries. In the present work, the large fault zones in the region and the general fault pattern are defined, mapped and described with the aid of satellite images. In addition, a large number of fault-slip data from the mesoscale exposed faults has been recorded, in order to better understand the faulting geometry and kinematics of the region. The stress-inversion analysis of these fault-slip data in comparison with earthquake faultplane solution information permits us to define the stress regimes imposed to the region from the Late Tertiary up to the present and to correlate them with the late orogenic and post-orogenic deformation of the Hellenic orogen. In particular, five stress regimes have been defined from which the former two (D1 and D2) are related to the late collisional processes between the Apulia and Eurasia plates, the next two events (D3 and D4) are related to the present-day Hellenic subduction zone, whereas the last D5 event which is the active deformation of the region appears as an intra-continental or intra-plate deformation more related with the Adria-Eurasia ongoing convergence rather with the Hellenic subduction zone.
\end{abstract}

Key words: stress regime, strike-slip faulting, extension, transpression, neotectonics.

\section{Introduction}

The Hellenic orogen constitutes part of the overriding Eurasia plate (Fig. 1) as the latter collided with the Apulia plate during Tertiary and evolved to the present Africa-Eurasia convergent plate system in the eastern Mediterranean (Mountrakis, 2006). Since Serravalian time, it is under a widely distributed extension (Le Pichon and Angelier, 1979) as it is suggested by seismological (McKenzie 1970, 1972; Papazachos et al., 1992) and neotectonic studies (Mountrakis et al. 2006; Kilias et al. 2008) and strain rates estimated by GPS measurements (Reilinger 1997; Kahle et al., 1998; McClusky et al. 2000). The present geotectonic regime, however, is much more complicated since this extension should accommodate: (a) the westward motion of Anatolia, (b) the retreating subduction of the Eastern Mediterranean lithosphere under Eurasia along the Hellenic Trench, and (c) the on- 
going continental collision between Adria and Eurasia (north of the Cephalonia Transform Fault), giving rise to the fold mountains of NW Greece and Albania.

Recently, attempts have been made to differentiate the Greek mainland into different domains regarding the stress regime and faulting deformational style (Doutsos and Kokkalas 2001, Papazachos and Kiratzi, 1996, Papazachos et al. 2001), but some of these results are under debate for several areas which are still poorly investigated.

One such area is the Kastoria-Nestorion region in NW-most Macedonia, which lies in the inner part of the Albanian-Pindos cordillera, far from the Hellenic subduction zone, and although it is characterized by low seismicity is crosscut by several big faults. Moreover, the large 1995 Grevena-Kozani earthquake of magnitude $\mathrm{M}=6.5$ that occurred ca. $55 \mathrm{~km} \mathrm{SE}$ of the study area as well as historical seismicity of the broader area (Papazachos and Papazachou 2003) verify that this characterization does not preclude the occurrence of large earthquakes in western Macedonia. Therefore, the main target of this paper is to provide the basic information on the faulting deformation and the active stress regime of this area, in order to better understand the neotectonic deformation and processes of the overriding Eurasia plate.

\section{Geological setting}

The Kastoria-Nestorion region is located in the Western Macedonia and the inner part of the Albanian-Pindos cordillera formed by the west-vergent thrust sheets, driven by the convergence and collision of the Apulia and Eurasia-Pelagonian continental blocks during the Late CretaceousEocene. It is an intermountainous area of low relief with respect to the high mountains in the west (Voios or Grammos Mt) and is drained by the large Aliakmonas River and its tributaries.

In this region, the Pindos cordillera is made up by Pindos and SubPelagonian isopic zones. The former (Crusta-Cukali zone in Albania) is a typical fold-and-thrust-belt of Mesozoic and Early Tertiary sedimentary rocks with successive thrusts and folds that verge towards WSW.

The above mentioned zones are covered in the Kastoria-Nestorion region by the Tertiary sedimentary molasse-type rocks that had filled up the NNW-SSE trending Mesohellenic Trough (MHT) (Fig. 1); a late-orogenic basin of c. $150 \mathrm{~km}$ length and $30 \mathrm{~km}$ width formed during the Late EoceneMiocene, i.e. the late stages of the main Tertiary Alpine orogenic processes. The MHT was developed along the inner slopes of the Albanian-Pindos cordillera over the ophiolites and Cretaceous limestones rocks that placed into the SubPelagonian zone (Mountrakis 1986). It was filled with up to $4 \mathrm{~km}$ marine turbidites, siliclastic shelf and terrigenous deposits that grouped into five main formations (Brunn 1956): (a) Krania Fm (of Late Eocene age), (b) Eptachori Fm (of Middle-Late Oligocene age), (c) Pentalofos Fm (of Aquitanian age), (d) Tsotyli Fm (of Late Aquitanian-Burdigalian age) and (e) Ontria Fm (of Burdigalian-Helvetian age). These formations form at a regional scale a homocline sequence that dips gently towards NE with the more to the east formations to be the younger ones.

More precisely, the Kastoria-Nestorion region is made up of molasse-type rocks that form the Pentalofos Fm, Tsotyli Fm and Ontria Fm. The Pentalofos Fm consists of thick $(<2500 \mathrm{~m})$ marine alternations of turbidite sandstone and shale, with minor conglomerate that divided into the Tsarnos and overlying Kalloni members. The Tsotyli Fm (thickness up to $1500 \mathrm{~m}$ ) rests onto the previous formation, as well as on the basement rocks. Its lower part consists of turbidite conglomerate alternated with sandstones, sandy marls and marlstones, and its upper part is dominated by bluish-grey clayey marlstones with sandy marly limestones interbeds. The Ontria Fm overlying the previous 


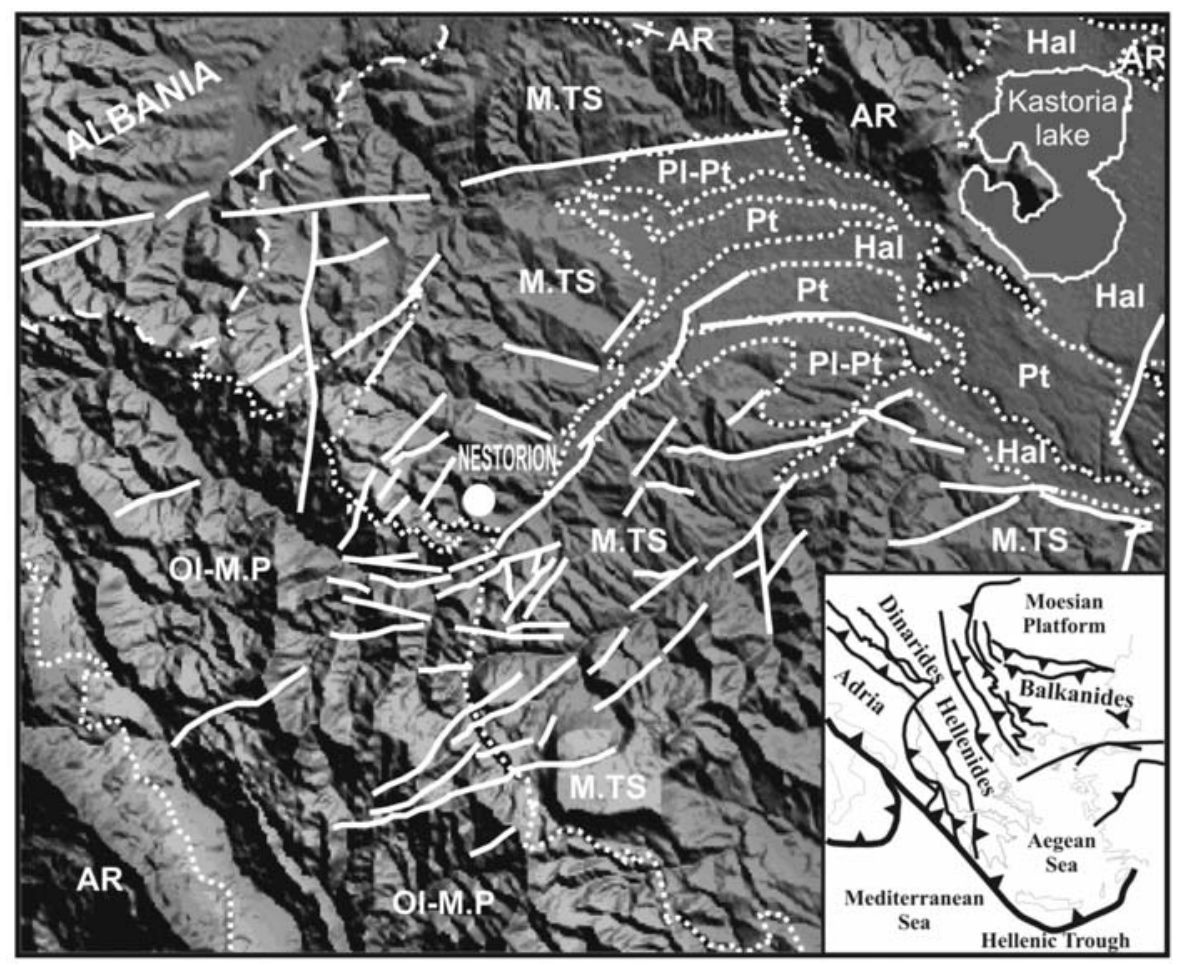

Fig. 1: Shaded relief image of the Kastoria-Nestorion region, Northwestern Macedonia showing the main faults. Geological units are shown as well. Inset map is showing the present-day geotectonic frame of the Southern Balkan. Explanation: Hal: Holocene alluvial deposits, Pt: Pleistocene deposits, Pl-Pt: Pliocene-Pleistocene deposits, M.TS: Tsotili Fm (Miocene), Ol-M.P: Pentalofos Fm (Oligocene-Miocene), AR: Alpine rocks (SubPelagonian zone). Dashed line: geological contact, solid line: Fault-Photolineament.

formation is a shallow clastic sequence (120-150m total thickness) that consists upwards of sandstones, marls and sandy-marly limestones. Its uppermost part is characterised by the presence of some lignite beds.

The Aliakmonas River draining the mountainous area drifts to the SSE, but in the Kastoria-Nestorion region changes its drift towards NE up to the Kastoria Lake and after that point obtains its SE drift again. The latter NE trend is also seen in the drift of other tributaries of the Aliakmonas River, i.e. the Zabourgiantziotikos River, a fact that could imply a tectonic origin.

The region as a part of the Albanian-Pindos cordillera has been subjected to different tectonic events since the main orogenic process that gave rise to the stacking of the units (Kilias et al. 2001). Previous studies have shown that the MHT appears to be a half graben, probably developed in a transtensional stress regime, along the suture zone of the Apulian and Pelagonian basement blocks (Doutsos et al., 1993; Zelilidis et al., 2002). The western margin of the basin has been seen either a steep eastverging thrust (Apulian thrust of Doutsos et al. (1994) or a right-lateral strike-slip fault, i.e., Eptahori fault (Kontopoulos et al. 1999; Vamvaka et al. 2006). In addition, the basin is internally deformed by a series of northwest-striking right-lateral strike-slip faults and east-striking left-lateral strike-slip faults (Doutsos et al., 1994). 
Since the late Miocene, the MHT has been mildly deformed by strike-slip motion along major faults along the western margin of the basin such as the Eptachori fault, uplifted, and eroded, with the oldest rocks exposed along the western marginal fault giving rise to the half graben geometry. However, a short period of compression was recognized in Middle-Late Miocene.

Information on the neotectonic regime of the area has been mainly derived by the studies that have been carried out in the region of Ptolemais and Kozani especially after the 1995 Kozani-Grevena earthquake of $\mathrm{M}=6.5$ (Pavlides and Mountrakis 1987; Mountrakis et al. 1996; Papazachos et al., 1998a; Mountrakis et al. 2006). These studies pointed out that the neotectonic deformation is accommodated through km-long normal faults driven by an NE-SW extension during the Late Miocene-Pliocene and an active NNW-SSE extension since the Quaternary, as also verified by seismological information (e.g. Papazachos et al., 1998b). Due to these stress regimes large faultbounded Neogene-Quaternary basins have been developed with the most well studied that of Ptolemais-Kozani-Servia basin.

\section{Structural data}

\subsection{Bedding of the molasse-type sedimentary rocks}

The bedding of the molasse-type sedimentary rocks in the Kastoria-Nestorion region dips as a rule very gently to the NNE (Fig. 2a). However, it has been found to reveal significant deviations with dips toward the ESE (Fig. 2b), a fact that it is attributed to the tilting of the bedding due more to the NE-SW striking faults that dip mainly towards NW than the folding of the region.

\subsection{Faulting}

Our study included the satellite interpretation of the landscape of the region in order to define the exposed large fault zones and the field recording of their geometry and kinematics, in order to define the driven stress regime. The fault pattern in the study region is dominated by: (a) NE-SW trending faults that affect mainly the molasse-type sediments. The drift of the Aliakmonas River and its tributaries seems to be controlled by these faults and the valleys formed are filled up only with Holocene alluvial sediments; (b) WNW-ESE to E-W trending faults that crosscut the previous ones and bound basins that are filled up with Pleistocene and Holocene sediments. However, the more precise description of the geometry and kinematics of the faults was based on subdividing the recorded fault-slip data into different groups, considering the orientation of the faults (dip and dip direction), as described by Tranos $(1998,2009)$. More specifically, the recorded in the field mesoscale faults (Fig. 3a) affecting the molasse-type sedimentary rocks were separated into the following groups according to their strike: 1) WNW-ESE striking faults that form two fault groups with mean dip-direction and dip values of $201-70^{\circ}$ and $033-61^{\circ}$, respectively (Fig. 3b, c), 2) NE-SW striking faults that form two fault groups with corresponding mean values $307-81^{\circ}$ and $300-58^{\circ}$, respectively (Fig. $3 \mathrm{~d}, \mathrm{e}$ ), and 3) NNW to N-S striking faults that form three fault groups with mean values $248-75^{\circ}$, $271-78^{\circ}$ and $084-78^{\circ}$, respectively (Fig. 3f, g, h).

\section{WNW-ESE striking faults}

The WNW-ESE striking faults include large faults and/or fault zones of width up to $10 \mathrm{~m}$ that dip either to SSW or to NNE. The NNE-dipping group includes fewer faults, more planar and with larger dispersion in strike with respect to the SSW-dipping group and although, they are also characterized by thinner fault zones they reveal similar multi-deformation history. Indeed, they both exhibit more than one generation of slickenlines that correspond to strike-slip displacements, younger normal dis- 


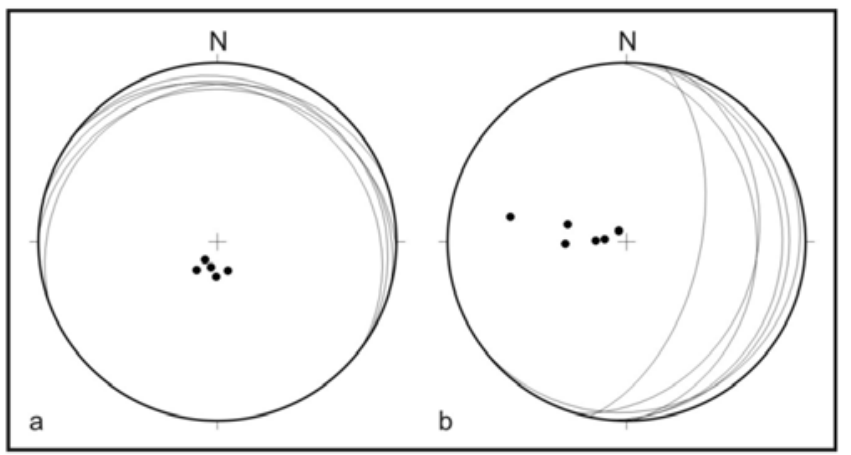

Fig. 2: Primary foliation of the molassic-type sedimentary rocks exposed in Kastoria-Nestorion region. (a) General attitude of the bedding, (b) Bedding attributed to the faulting.

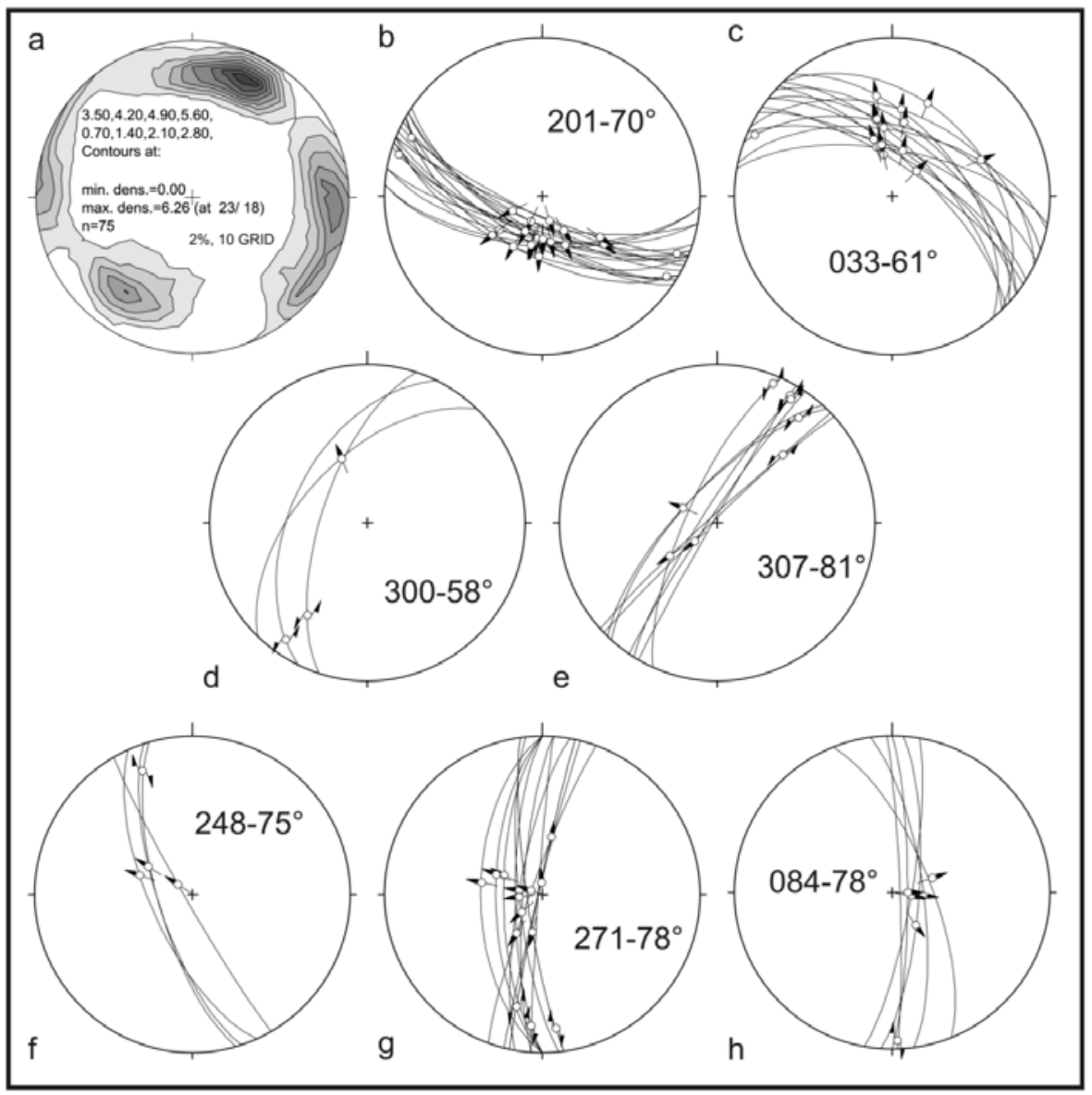

Fig. 3: Stereographic projections (equal area, lower hemisphere) indicating the geometry and kinematics of the mesoscale faults recorded in the Kastoria-Nestorion region. (a) Density diagram of the poles of the mesoscale faults, (b, c) Fault planes and striations of the WNW-ESE striking mesoscale fault groups, (d, e) the NE-SW striking mesoscale faults, and (f, $g, h$ ) the NNW-SSE to N-S striking mesoscale faults. 
placements that overprinted by left-lateral oblique normal ones. However, the majority of the faults can be fairly described as synthetic or antithetic quasi-Andersonian faults in the field, having as a remarkable feature the drag folding of the bedding of the molasse-type rocks due to their activation.

\section{NE-SW striking faults}

The NE-SW striking faults are the longer faults exposed in the region, forming km-long fault zones with a width of several meters. They control the hydrographic network and the recent topography of the region and cut the WNW-ESE striking faults. In particular, faults of this strike control the eastern slopes of the Aliakmonas River (area of Pentavrissos-Omorphoklisia) forming successive fault zones within the bedding of the molasse tilting at various angles. The NE-SW striking faults, which are not prevalent in the mesoscale, exhibit at least two generations of slickenlines, which correspond to strikeslip displacements and younger normal ones. The latter displacements show significant dispersion, but with the clear distinction of the right normal from the left-lateral normal ones.

\section{NNW-SSE to N-S striking faults}

These faults form narrow fault zones, the commonest width of which is approximately $30 \mathrm{~cm}$. They commonly form splay or bridge faults between the larger NE-SW striking faults and dip at very high angles or are nearly vertical; however along these faults one can hardly see drag folds. The slickenlines of the faults indicate strike-slip displacements overprinted by younger normal ones.

\subsection{Fault-slip analysis and stress regimes}

The above mentioned fault groups have been studied using the stress-inversion methods of Angelier (1984) and Gephart and Forsyth (1984). For this reason, the fault groups have been separated using field observations, such as overprinting of the slickenlines contained by faults and cross-cutting criteria among the different faults groups. In addition, the fault grouping has also considered the fault type and transport orientation. The stress pattern has been characterized using the type of the most vertical axis and the stress ratio of the resolved stress tensor, following the suggestion of Tranos et al. (2008). The same procedure has been applied for 23 focal mechanisms of earthquakes that occurred in the broader Kastoria-Nestorion region $\left[39.8-40.8^{\circ} \mathrm{N}, 20.8-22^{\circ} \mathrm{E}\right]$ within the last 25 years, either compiled for this work from the waveform data of the seismological network of the Aristotle Univ. Thessaloniki (http://seismology.geo.auth.gr) or from various sources (Papazachos and Papazachou, 2003; Mountrakis et al., 2006) in order to assess the active stress field of the region and to compare the stresses defined by fault-slip data and focal mechanisms.

In all cases both applied stress inversion methods provided very compatible results regarding the stress tensor orientation, despite sometimes significant differences regarding the stress ratio value. In the following, the stress pattern for each defined fault group is presented. For the Gephart and Forsyth (1984) approach we also present all compatible solutions within the 95\% confidence area, while the final stress solution corresponds to the average (in the least square sense) stress tensor of this confidence area, rather than the optimum solution, which in some cases was located at the border of the confidence area and exhibited negligibly smaller misfit values with respect to the average solution. Therefore, the following stress regimes have been defined:

\section{D1 event (TRP-SS)}

This is a transpressional - strike-slip regime associated with NNE-SSW contraction in which the stress tensor has $\sigma_{2}$ vertical axis and stress ratio $\mathrm{R}=0.24$ (Fig. 4a). It activated NNW-SSE striking faults as right-lateral strike-slip faults and NNE-SSW to NE-SW striking faults as left-lateral strike- 


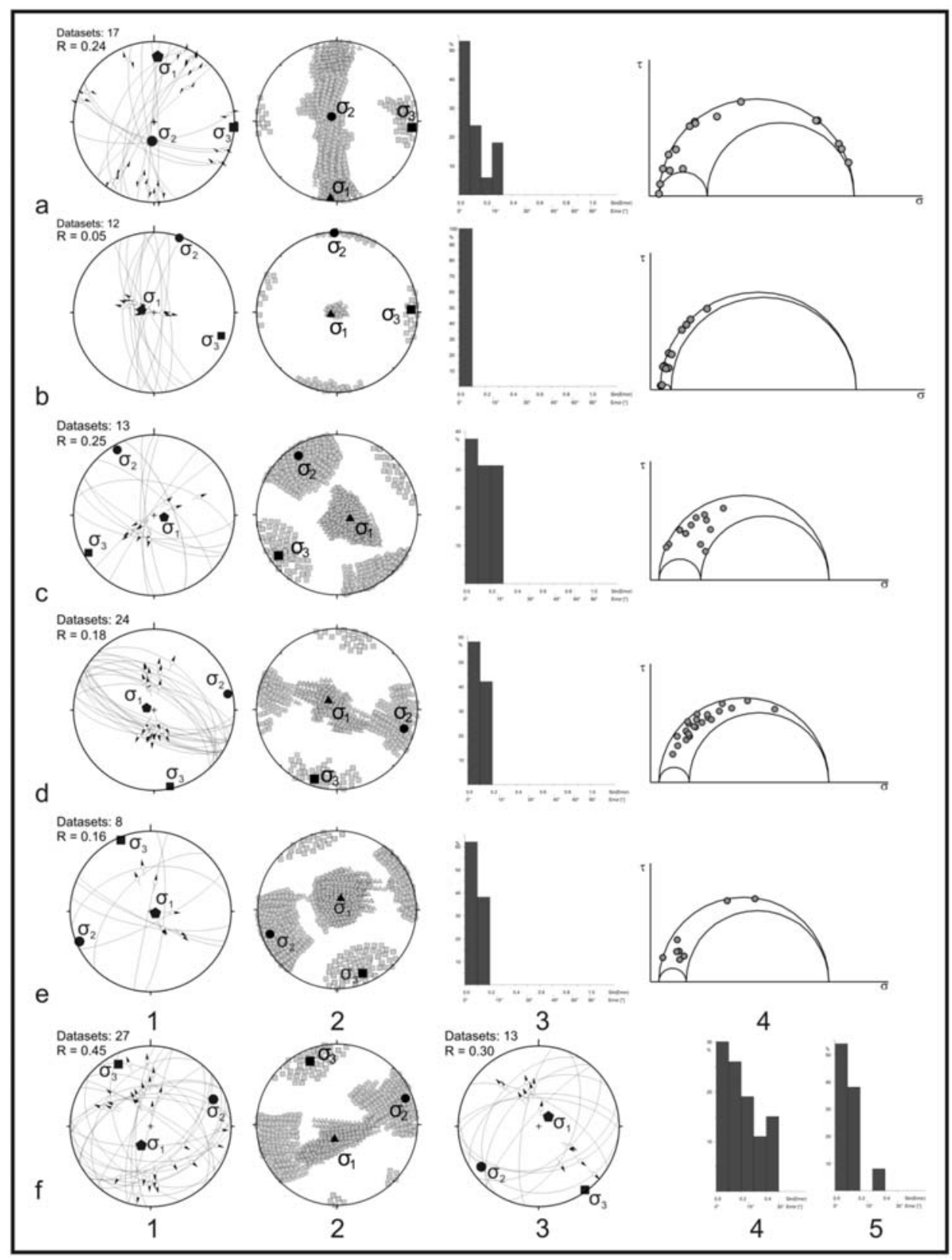

Fig. 4: Stereographic projections (equal area, lower hemisphere) indicating the broader Kastoria-Nestorion area fault-slip and earthquake focal mechanism data activated in the various deformational events: (a) D1 event, (b) D2 event, (c) D3 event, (d) D4 event, (e) D5 event, (f) active stress field from focal mechanisms (see text). Explanation: 1. Fault-slip data and the stress axes from Angelier (1984) method, 2. Average stress axes and 95\% confidence area solutions for the Gephart and Forsyth (1984) method, for a, b, c, d, e: 3 \& 4. Distribution of the misfit angle between the real and theoretical striae and Mohr diagram from Angelier (1984) method. Only for f: 3 . Improved solution with Angelier method (after rejecting those of high misfit angle $\left(>20^{\circ}\right), 4$ and 5 : Misfit angles for $\mathrm{f} 1$ and $\mathrm{f} 3$ solutions respectively. 
slip faults. The small number of the WNW-ESE trending strike-slip faults, the sense of which is not certain from field data, fits well with the stress tensor if they act as right-lateral strike-slip faults, i.e. as R' shears. This event affected the molasse-type sediments of Pentalofos and Tsotyli formations, hence is timely constrained after the Early Miocene (Burdigalian). This stress field does not operate later than the beginning of Late Miocene, considering that Late Miocene and younger sediments have not been affected by similar in geometry and kinematics strike-slip faults.

\section{D2 event (RE)}

This event corresponds to an almost radial extension with a vertical $\sigma_{1}$ axis and an extensional stress axis $\sigma_{3}$ oriented subhorizontal along WNW-ESE (Fig. 4b). It activated the previous NNW-SSE to NNE-SSW striking faults as normal faults, with a slip direction trending WNW-ESE. This event should be dated in Middle-Late Miocene, since its corresponding faults have not affected sediments younger than Late Miocene. The fact that the $\sigma_{3}$ axis trends in the same direction as with the previous D1 event suggests that D1 probably evolved progressively to D2, whereas a slip partitioning can be also locally considered, with either normal or strike-slip activation.

\section{D3 event (RE-PE)}

This event is defined as a NE-SW extensional stress field with a vertical compression $\left(\sigma_{1}\right)$ and subhorizontal extension $\left(\sigma_{3}\right)$ trending NE-SW (Fig. 4c). It activated NNW-SSE striking faults and WNW-ESE striking faults as left-lateral oblique normal faults and right-lateral oblique normal faults, respectively. In addition, NW-SE striking faults were activated as normal faults in this stress field. This deformation event has been very well constrained by several published studies for Northern Greece during the Late Miocene and Pliocene (Pavlides and Mountrakis 1987; Mercier et al. 1989; Mountrakis et al.2006).

\section{D4 event (RE-PE)}

This event is described as an extensional stress regime, associated with N-S to NNE-SSW extension and a vertical $\sigma_{1}$ axis (Fig. 4d). The activated faults are quasi-Andersonian WNW-ESE synthetic and/or antithetic normal faults forming a fault system. During this event, the slip direction, as defined by the fault-slip data, trends N-S. Previously published studies date this event in Quaternary times (Pavlides and Mountrakis 1987; Mercier et al. 1989; Tranos and Mountrakis 1998; Mountrakis et al. 2006), as confirmed by the generally E-W trending basins of the wider area, which are bounded by E-W trending faults and are filled up with Pleistocene and Holocene sediments.

\section{D5 event (RE-PE)}

This event is also described by a subhorizontal $\sigma_{3}$ axis trending NNW-SSE and a vertical $\sigma_{1}$ axis mainly activating NE-SW striking faults as normal and right-lateral normal faults (Fig. 4e). From the family of NNW-SSE to NNE-SSW faults, the NNE-SSW ones are also activated during this event as right-lateral oblique faults. More importantly, the WNW-ESE striking faults are also activated in this event, however not as normal faults but as right-lateral oblique ones. The defined extension stress axis $\left(\sigma_{3}\right)$ is in very good agreement with stress defined using the focal mechanisms of medium (typically $\mathrm{M} \sim 3.5-4.0)$ to large ( $\mathrm{M}$ 5.5-6.5) earthquakes of the broader western Macedonia area (Fig. 4f), including the earthquake activity related with the Grevena-Kozani earthquake (Papazachos et al., 1998a). It should be pointed out that despite the fact that several medium magnitude events in the immediate vicinity of the Kastoria-Nestorion area exhibited even NNE-SSW T-axes, the inverted stress field shows a clear NNW-SSE extensional stress field (in agreement with Fig. 4f), as also confirmed by an independent stress inversion of only these narrower Kastoria-Nestorion area data. We 
propose that this D5 event should be dated in Holocene, since the valleys along the corresponding faults are filled up only with Holocene alluvial sediments instead of the WNW-ESE basins that are filled up with both Pleistocene and Holocene sediments.

\section{Conclusions-Results}

The MHT in the Kastoria-Nestorion region of NW Macedonia indicates a multi-deformed history, not only during its early stages, but also during the Late Tertiary and Quaternary time as herein indicated by the present analysis of faulting. More interest is the fact that the herein described Late Tertiary-Quaternary deformation of the MHT can be correlated with the deformation of North Aegean Trough and the Hellenic hinterland (Tranos 1998, 2009; Georgiadis et al. 2007; Tranos et al. 2008, 2009). In particular, five deformation events have been defined to affect the MHT using the faultslip data recorded in the Kastoria-Nestorion region and the use of stress-inverse methods of Angelier (1984) and Gephart and Forsyth (1984), respectively. The former three ones, D1, D2 and D3 dominated the region during the Neogene, whereas the last two events D4 and D5 from Quaternary to present. In particular, our analysis suggests that the MHT was initially subjected to a regional transpressional-strike-slip regime in the Miocene times, which can be attributed to the late collision processes between the Eurasia and Apulia plates. The D2 event represents a progressive stage of the D1 event associated with the latest stages of the collision processes. On the other hand, the next faulting deformation (D3 event) was a NE-SW to ENE-WSW extension that relates with the onset of the present-day Hellenic subduction zone and gave rise to the large NW-SE trending fault-bounded basins developed in Macedonia region in the Late Miocene and Pliocene times. More importantly, our analysis suggests that during the Quaternary, probably close to the Late Pleistocene-Holocene boundary, the least principal stress axis of the extensional stress field changed from NNE-SSW (D4 event) to NNW-SSE trend (D5 event). This gradual anticlockwise rotation of the NE-SW extension (D3) to NNE-SSW (D4) and finally NNW-SSE (D5) suggests that the stress regime which is commonly interpreted as a back-arc extension to the present-day Hellenic subduction zone, since it trends orthogonal to it, should have changed to a rather intra-continental or intra-plate deformation. Indeed, the orientation of the least principal contemporary stress axis appears to be more related with the Adria-Eurasia evolved convergence since the former trends along the Dinarides-Hellenides rather the present-day Hellenic subduction zone.

\section{References}

Angelier, J., and Mechler, P. 1977. Sur une méthode graphique de recherche des contraintes principales également utilisable en tectonique et enséismologie: la methode des diédres droits. Bull. Soc. Géol. France, 7(19), 1309-1318.

Angelier, J., 1984. Tectonic analysis of fault slip data sets. J. Geophys. Res., 89, 5835-5848.

Brunn, J. H., 1956. Contribution á l' étude géologique du Pinde septentrionale et d'une partie de la Macédoine occidentale. Annales Géologiques des Pays Helléniques, 7, 1-358.

Doutsos, T., and Kokkalas, S., 2001. Stress and deformation patterns in the Aegean region, J. Struct. Geol., 23, 455 - 472 .

Doutsos, T., G. Pe-Piper, G., Boronkay, K. and Koukouvelas, I., 1993. Kinematics of the central Hellenides. Tectonics, 12, 936-953.

Doutsos, T., Koukouvelas, I., Zelilidis, A. and Kontopoulos, N., 1994 . Intracontinental wedging and postorogenic collapse in the Mesohellenic trough. Geol. Rundsch., 83, 257-275.

Georgiadis, G. A., Tranos, M. D. and Mountrakis, D. M., 2007. Late-and post-Alpine tectonic evolution 
of the southern part of the Athos peninsula, northern Greece. Bull. Geol. Soc. Greece, 40, 309-320.

Gephart, J. W. and Forsyth, D. W., 1984. An improved method for determining the regional stress tensor using earthquake focal mechanism data: an application to the San Fernando earthquake sequence. $J$. Geophys. Res., BS9, 9305-9320.

Le Pichon, X., and Angelier, J., 1979. The Hellenic Arc and Trench system: A key to the neotec-tonic evolution of the eastern Mediterranean area. Tectonophysics, 69, $1-42$.

Kahle, H. G., Straub, C., Reilinger, R., McClusky, S., King, R., Hurst, K., Veis, G. and Cross, P., 1998. The strain rate field in the eastern Mediterranean region, estimated by repeated GPS measurements. Tectonophysics, 294, $237-252$.

Kilias, A. A., Tranos, M. D., Papadimitriou, E. E., and Karakostas, V. G., 2008. The recent crustal deformation of the Hellenic orogen in Central Greece; the Kremasta and Sperchios Fault Systems and their relationship with the adjacent large structural features. Z. dt. Ges. Ge-owiss., 159/3, 533-547. DOI: 10.1127/1860-1804/2008/0159-0533.

Kilias, A., Tranos, M., Mountrakis, D., Shallo, M., Marto, A. and Turku, I. 2001. Geometry and kinematics of deformation in the Albanian orogenic belt during the Tertiary. J. Geodyn., 31, 169-187.

Kontopoulos, N., Fokianou, T., Zelilidis, A., Alexiadis, C. and Rigakis, N., 1999. Hydrocarbon potential of the middle Eocene-middle Miocene Mesohellenic piggy-back basin (central Greece): a case study. Mar. Petrol. Geol., 16, 811-824.

McClusky, S., et al. (28 authors) 2000. Global Positioning System constraints on plate kinematics and dynamics in the eastern Mediterranean and Caucasus. J. Geophys. Res., 105, 5695-5719.

McKenzie, D.P. 1970. The plate tectonics of the Mediterranean region. Nature, 226, 239-243.

McKenzie, D.P. 1972. Active tectonics of the Mediterranean region. Geophys. J. R. astr. Soc., 30, 109-185.

Mercier, J. L., Simeakis, K., Sorel, D., and Vergely, P., 1989. Extensional tectonic regimes in the Aegean basins during the Cenozoic. Basin Research, 2, 49-71.

Mountrakis, D. 1986. The Pelagonian zone in Greece: A polyphase-deformed fragment of the Cimmerian continent and its role in the geotectonic evolution of the eastern Mediterranean. J. Geol., 94, 335-347.

Mountrakis, D., Pavlides, S., Zouros, N., Chatzipetros, A. and Kostopoulos, D., 1996. The 13 May 1995 Western Macedonia (Greece) earthquake. Preliminary results on the seismic fault geometry and kinematics. Proceedings of the XV Congress of the Carpatho-Balkan Geological Association, Seismicity of the Balkan region, 112-121.

Mountrakis, D., 2006. Tertiary and Quaternary tectonics of Greece, in Dilek, Y., Pavlides, S., eds., Postcollisional tectonics and magmatism in the Mediterranean region and Asia. Geological Society of America, Special Paper, v. 409, p. 125-136. DOI: 10.1130/2006.2409(07).

Mountrakis, D., Tranos, M., Papazachos, C., Thomaidou, E., Karagianni, E., and Vamvakaris, D., 2006. New neotectonic and seismological data about the main active faults and stress regime of Northern Greece. J. Geol. Soc., London, Sp. Publ., 260, 649-670.

Papazachos, B. C., Karakostas, B. G., Kiratzi, A. A., Papadimitriou, E. E. and Papazachos, C. B., 1998a. Basic properties of the faulting which caused the 1995 Kozani-Grevena seismic sequence. J. Geodyn., 26, 217-231.

Papazachos, B.C., Papadimitriou, E.E., Kiratzi, A.A., Papazachos, C.B. and Louvari, E.K., 1998b. Fault plane solutions in the Aegean Sea and the surrounding area and their tectonic implications, Boll. Geof. Teor. Appl., 39, 199-218.

Papazachos, B., Mountrakis, D., Papazachos, C., Tranos, M., Karakaisis, G. \& Savvaidis, A. 2001. The faults which have caused the known major earthquakes in Greece and surrounding region between the 5th century BC and today. Proceedings of the 2nd Panhellenic Congress of Earthquake Engineering and 
Engineering Seismology, 28-30 September. Technical Chamber of Greece, Thessaloniki, 1, 17-26.

Papazachos, B., and Papazachou, C., 2003. The Earthquakes of Greece. Editions Ziti, Thessaloniki, 1-317.

Papazachos, C.B., Kiratzi, A.A. and Papazachos, B.C., 1992. Rates of active crustal deformation in the Aegean and the surrounding area. J. Geodyn., 16, 147-179.

Papazachos, C.B. and Kiratzi, A.A., 1998. A detailed study of the active crustal deformation in the Aegean and surrounding area. Tectonophysics, 253, 129-153.

Pavlides, S. and Mountrakis, D., 1987. Extensional tectonics of north-west Macedonia, Greece, since the Late Miocene. J. Struct. Geol., 9, 385-392.

Reiter, F. and Acs, P., 2003. TectonicsFP software. http://www.tectonicsfp.com.

Reilinger, R. E., McClusky, S. C., Oral, M. B., King, R. W., Toksoz, M. N., Barka, A. A., Kinik, I., Lenk, O. and Sanli, I., 1997. Global positioning system measurements of present crustal movements in the Arabia-Africa-Eurasia plate collision zone. J. Geophys. Res., 102, 9983-9999.

Tranos, M. D., 1998. Contribution to the study of the neotectonic deformation in the region of Central Macedonia and North Aegean. PhD. Thesis, University of Thessaloniki, (in Greek with extended English abstract).

Tranos, M.D., 2009. Faulting of Lemnos Island; a mirror of faulting of the North Aegean Trough (Northern Greece). Tectonophysics, 467, 72-88, DOI: 10.1016/j.tecto.2008.12.018.

Tranos, M. D., Kachev, V. N., and Mountrakis, D. M., 2008. Transtensional origin of the NE-SW Simitli basin along the Strouma (Strymon) Lineament, SW Bulgaria. J. Geol. Soc. London, 165, 499-510, doi: 10.1144/0016-76492007-089

Tranos, M. D., Eleftheriadis, G. E., Kilias, A. A., 2009. Philippi granitoid as a proxy for the Oligocene and Miocene crustal deformation in the Rhodope Massif (Eastern Macedonia, Greece). Geotectonic Research, 96, 69-85.

Tranos, M. D. and Mountrakis, D. M., 1998. Neotectonic joints of Northern Greece: their signi-ficance on the understanding of the active deformation. Bull. Geol. Soc. Greece, 32, 209-219.

Vamvaka, A., Kilias, A., Mountrakis, D. and Papaoikonomou, J., 2006. Geometry and structural evolution of the Mesohellenic Trough (Greece): a new approach. J. Geol. Soc. London, Sp. Publ., 260, 521-538, doi: 10.1144/GSL.SP.2006.260.01.22

Zelilidis, A., Piper, D. J. W. and Kontopoulos, N., 2002. Sedimentation and basin evolution of the Oligocene-Miocene Mesohellenic basin, Greece. AAPG Bulletin, 86, 161-182. 